\title{
Communication
}

\section{Diaportheone A Analogues Instigate a Neuroprotective Effect by Protecting Neuroblastoma SH-SY5Y Cells from Oxidative Stress}

\author{
Mario A. Tan ${ }^{1,2, *}$, Elena Zakharova ${ }^{3}$ and Seong Soo A. An ${ }^{1, *}$ \\ 1 Department of Bionano Technology, Bionano Research Institute, Gachon University, 1342 Seongnam-daero, \\ Sujung-gu, Seongnam-si 461-701, Korea \\ 2 College of Science and Research Center for the Natural and Applied Sciences, University of Santo Tomas, \\ Espana, Manila 1015, Philippines \\ 3 Department of Chemistry and Biochemistry, University of Bern, Freiestrasse 3, 3012 Bern, Switzerland; \\ elena.zakharova@dcb.unibe.ch \\ * Correspondence: matan@ust.edu.ph (M.A.T.); seongaan@gachon.ac.kr (S.S.A.A.); \\ Tel.: +63-2-7314031 (M.A.T.); +82-31-7508755 (S.S.A.A.)
}

check for updates

Citation: Tan, M.A.; Zakharova, E.; An, S.S.A. Diaportheone A Analogues Instigate a Neuroprotective Effect by Protecting Neuroblastoma SH-SY5Y Cells from Oxidative Stress. Biology 2021, 10, 199. https://doi.org/ 10.3390/biology10030199

Academic Editor: Pilar Roca

Received: 12 February 2021

Accepted: 2 March 2021

Published: 5 March 2021

Publisher's Note: MDPI stays neutral with regard to jurisdictional claims in published maps and institutional affiliations.

Copyright: (c) 2021 by the authors. Licensee MDPI, Basel, Switzerland. This article is an open access article distributed under the terms and conditions of the Creative Commons Attribution (CC BY) license (https:// creativecommons.org/licenses/by/ $4.0 /)$.
Simple Summary: Alzheimer's disease is a progressive neurodegenerative illness affecting mostly elderly people. Preventing the neurotoxicity caused by the formation of amyloid-beta plaques and oxidative stress is one of the key strategies to minimize the effects of this disease. Hence, our study aims to search for compounds which may exhibit neuroprotective potential using the human neuroblastoma SH-SY5Y cells induced with oxidative stress as our cellular model. Our library of compounds showed that diaportheones A1 and A2 protected the formation of amyloid-beta plaques using the ThT assay and exhibited neuroprotective effects in damaged SH-SY5Y cells. The preventive effect of the compounds on the aggregation of amyloid-beta was also shown by molecular modelling. Thus, diaportheones A1 and A2 could be potential compounds for further studies against Alzheimer's disease.

Abstract: Alzheimer's disease (AD) remains an incurable neurodegenerative illness. Oxidative stress resulting in the formation of reactive oxygen species (ROS) and the abnormal deposition of amyloidbeta $(\mathrm{A} \beta)$ are the major pathological hallmarks associated with $\mathrm{AD}$. In search for small molecules targeting multiple pathways of $\mathrm{AD}$ and of no known molecular targets, the neuroprotective effects of the synthetic chromones diaportheone A1 and diaportheone A2, analogues of the natural product diaportheone A, were investigated. Chromones are heterocyclic compounds bearing the benzoannelated $\gamma$-pyrone moiety and were regarded as an important class of organic molecules due to their diverse pharmacological activities. The influence of the compounds on the inhibition of A $\beta$ aggregation was determined by Thioflavin T (ThT) assay, and the cell viability, ROS, and mitochondrial membrane potential were evaluated with human neuroblastoma SH-SY5Y cells. Results showed that both compounds inhibited the $\mathrm{A} \beta$ aggregation at $80.41 \%$ and $73.68 \%$ for diaportheone $\mathrm{A} 1$ and diaportheone $\mathrm{A} 2$, respectively. Increased cell viabilities were observed from the protection by both compounds using $\mathrm{A} \beta$ - or $\mathrm{H}_{2} \mathrm{O}_{2}$-induced SH-SY5Y cells. Both compounds also reduced the intracellular ROS level in $\mathrm{A} \beta$ - or $\mathrm{H}_{2} \mathrm{O}_{2}$-induced SH-SY5Y cells at 10 and $20 \mu \mathrm{M}$ concentrations, and increased the mitochondrial membrane potentials in A $\beta$-induced SH-SY5Y cells at $20 \mu \mathrm{M}$ concentration. Molecular docking experiments using the $\mathrm{A} \beta$ protein models $2 \mathrm{MXU}$ and $2 \mathrm{BEG}$ also indicated a good agreement with the experimental data. The results demonstrated for the first time the oxidative stress effects associated with the chromones diaportheone A1 and diaportheone A2 as potential neuroprotective therapeutic agents against AD.

Keywords: Alzheimer's disease; amyloid-beta; chromone; molecular docking; oxidative stress 


\section{Introduction}

Alzheimer's disease (AD) remains an incurable neurodegenerative illness among elderly people and is characterized by memory loss, dementia, and the progressive deterioration of cognition and language skills [1]. Many research investigations are continuously revealing the vast interconnected complex systems with genetic and biochemical factors for better understanding its pathogenicity [2-5]. The worldwide population estimates that around 47 million elderly people are affected by the disease, with the number rising to 131 million in 2050 [6]. Although there is no cure yet for AD, four drugs targeting acetylcholinesterase and one drug targeting $N$-methyl-D-aspartate receptor are currently available to reduce the symptoms of AD patients [7]. Strategic treatments in the early stage of $\mathrm{AD}$ detection are also proven to be beneficial [8].

Oxidative stress is usually involved in the production of high level of reactive oxygen species (ROS) and reactive nitrogen species, resulting in the significant reduction of the cellular antioxidant defenses [9]. In general, ROS contributes to biological processes such as cellular metabolic regulations and are in equilibrium with the endogenous antioxidant system [10]. However, an imbalance in the system producing more ROS leads to oxidative damage in the cellular structure and cell death [10]. Hence, oxidative stress is associated as a leading cause of neurodegenerative diseases such as AD, Parkinson's disease, amyotrophic lateral sclerosis (ALS), and even stroke [10]. Oxidative stress resulting in the formation of ROS and the abnormal deposition of amyloid-beta $(\mathrm{A} \beta)$ are the major pathological hallmarks associated with $\mathrm{AD}$ [9]. The association of the oxidative stress and the formation of $A \beta$ aggregates leading to oxidative damages to neurons in cell culture, to $A D$ animal models, and the human brain were well documented [11-14]. Hence, the discovery of drugs multi-targeting the inhibition of $A \beta$ aggregation and oxidative stress is eagerly warranted.

Due to the chemical diversity of small molecules, whether synthetically derived or isolated from natural products, many compounds were subjected to intense AD research for potential leads in the field of drug discovery and development. Various chemical scaffolds belonging to the alkaloids, phenolics, terpenoids, flavonoids, glucosides, and saponins exhibit protective effects using in vitro and in vivo models [15]. The plant-derived alkaloids galantamine and rivastigmine are examples of approved anti-AD drugs targeting the acetylcholinesterase (AChE) pathway [7]. Small molecules reported in the literature demonstrated their potential for anti-AD drug discovery as inhibitors of neuroinflammation, tau protein hyperphosphorylation [16], neuroprotective effects against $\mathrm{A} \beta$ toxicity, aggregation, or oligomerization [7,17], or the reduction of oxidative stress [18]. However, due to the complexity of the $\mathrm{AD}$, the search for small molecules targeting multiple pathways should be essential as an alternative mechanism to potential AD therapy [7]. Hence, this study examined the neuroprotective ability of the synthetic chromone molecules diaportheone A1 and diaportheone A2 in vitro, using the neuroblastoma SH-SY5Y cells. Literature search indicated no known molecular targets or biological activities associated with these compounds. Neuroblastoma SH-SY5Y cells were induced with $\mathrm{A} \beta_{1-42}$ or $\mathrm{H}_{2} \mathrm{O}_{2}$ to determine the neuroprotective effects, and the Thioflavin $\mathrm{T}$ (ThT) assay was used to assess their inhibition of $A \beta$ aggregation.

\section{Materials and Methods}

\subsection{Thioflavin $T$ (ThT) Assay}

The procedure for the ThT assay was previously reported $[2,19,20]$. Briefly, $A \beta_{1-42}$ (Aggresure $^{\mathrm{TM}}$ (AnaSpec) Fremont, CA, USA) was dissolved in phosphate buffered saline (PBS) and incubated with or without the compounds or phenol red (positive control) at $37^{\circ} \mathrm{C}$ for $24 \mathrm{~h}$. ThT solution was added and incubated for $15 \mathrm{~min}$. Fluorescence signal (Ex $450 \mathrm{~nm}$; Em $510 \mathrm{~nm}$ ) was measured using a PerkinElmer Victor-3®multi-plate reader (PerkinElmer, Waltham, MA, USA). The percentage of aggregation inhibition was calculated using the following equation: $\left[\left(1-I_{\mathrm{Fi}} / I_{\mathrm{Fc}}\right) \times 100 \%\right]$, where $I_{\mathrm{Fi}}$ and $I_{\mathrm{Fc}}$ are the fluorescence absorbance with and without the inhibitors, respectively, after subtracting the background fluorescence of the ThT solution. 


\subsection{Cell Culture}

Human neuroblastoma SH-SY5Y cells (American Type Culture Collection, ATCC CRL2266) (Manassas, VA, USA) were maintained in Dulbecco's modified eagle media (DMEM) supplemented with $10 \%$ fetal bovine serum (FBS), $1 \%$ kanamycin, and $1 \%$ penicillin at $37^{\circ} \mathrm{C}$ and $5 \% \mathrm{CO}_{2}$, and passaged once per week. Experiments were performed at $80-90 \%$ cell confluence.

\subsection{Cell Cytotoxicity}

Cell viability measurement was performed using the ATP luminescence assay as previously described $[19,20]$. SH-SY5Y cells were counted by Eve cell counter (NanoEntek, Inc., Seoul, Korea), and $2 \times 10^{4}$ cells /well density were sub-cultured in 96-well plate and incubated for $24 \mathrm{~h}$. After incubation, cells were treated with the compounds for $24 \mathrm{~h}$. The media were removed, cells were washed with PBS, fresh media were added, and incubated for another $30 \mathrm{~min}$. Then, CellTiter-Glo ${ }^{\circledR}$ (Promega, Madison, WI, USA) luminescent reagent was added and the luminescence was read on a PerkinElmer Victor- $3^{\circledR}$ multi-plate reader. Data were analyzed and the \% cell viability was expressed relative to the control.

\subsection{Neuroprotective Activity Assay}

Determination of the neuroprotective activity in $\mathrm{A} \beta$ or $\mathrm{H}_{2} \mathrm{O}_{2}$-induced SH-SY5Y cytotoxicity was performed as previously described $[21,22]$ and evaluated by the ATP luminescence assay as described above. Neuroblastoma SH-SY5Y cells were seeded in a 96-well plate at $2 \times 10^{4}$ cells/well and incubated for $24 \mathrm{~h}$. After stabilization, cells were pre-treated with the compounds for $6 \mathrm{~h}$ before incubation with $\mathrm{A} \beta(5 \mu \mathrm{M})$ or $\mathrm{H}_{2} \mathrm{O}_{2}(100 \mu \mathrm{M})$ for $24 \mathrm{~h}$. A solvent control (untreated control cells), $\mathrm{A} \beta$ or $\mathrm{H}_{2} \mathrm{O}_{2}$ alone, and the compounds alone treatments were also included. After incubation, the \% cell viability was determined in triplicate experiments.

\subsection{Measurement of Reactive Oxygen Species (ROS)}

Intracellular ROS level measurement was performed using the $2^{\prime}, 7^{\prime}$-dichlorodihydrofluorescein diacetate $\left(\mathrm{H}_{2}\right.$ DCFDA) (Sigma Aldrich, St. Louis, MO, USA) staining method, as previously described [21,23]. After $24 \mathrm{~h}$ acclimatization, SH-SY5Y $\left(2 \times 10^{4}\right.$ cells/wells $)$ cells were pre-treated with the compounds for $2 \mathrm{~h}$ before incubation, with $5 \mu \mathrm{M} \mathrm{A} \beta$ for $24 \mathrm{~h}$ or $100 \mu \mathrm{M} \mathrm{H}_{2} \mathrm{O}_{2}$ for $4 \mathrm{~h}$. Cells were then treated with $25 \mu \mathrm{M} \mathrm{H}_{2}$ DCFDA and incubated for $2 \mathrm{~h}$ in the dark at $37^{\circ} \mathrm{C}$. Fluorescence intensity (Ex $495 \mathrm{~nm}, \mathrm{Em} 520 \mathrm{~nm}$ ) was measured in a microplate reader. The ROS level was calculated as a percentage of the untreated control cells $(100 \%)$ in triplicate measurements.

\subsection{Mitochondrial Membrane Potential ( $\Delta \Psi m)$ Assay}

Measurement of the $\Delta \Psi \mathrm{m}$ was performed using the tetramethylrhodamine, methyl ester (TMRE) (Abcam TMRE mitochondrial membrane kit) staining method as previously described [24] and following the manufacturer's protocol. SH-SY5Y $\left(2 \times 10^{4}\right.$ cells/well $)$ cells were pre-treated with the compounds for $2 \mathrm{~h}$, and incubated together with $5 \mu \mathrm{M}$ $\mathrm{A} \beta$ for $24 \mathrm{~h}$. After treatment, $1 \mu \mathrm{M}$ TMRE staining solution was added and incubated at $37{ }^{\circ} \mathrm{C}$ for $1 \mathrm{~h}$. The fluorescence (Ex $549 \mathrm{~nm}$, Em $575 \mathrm{~nm}$ ) was read in a microplate reader. The $\Delta \Psi \mathrm{m}$ was calculated as a percentage of the untreated control cells $(100 \%)$ in triplicate measurements.

\subsection{Molecular Docking}

The software AutoDock Tools (La Jolla, CA, USA) (version 1.5.6) [25] was used to perform a blind docking of diaportheone $\mathrm{A} 1$ and diaportheone $\mathrm{A} 2$ into ten protein models of the recently resolved NMR structures of A $\beta 42$ fiber (PDB codes: $2 \mathrm{BEG}$ and $2 \mathrm{MXU})[26,27]$ as follows. Polar hydrogens and Kolman charges were added to the receptor. The Lamarckian genetic algorithm (GA) was used for ligand conformation search with the following parameters: number of GA runs 50; population size 300; the other parameters are 
default. Since the molecule has only two rotatable bonds, the applied procedure is reliable to find putative binding sites.

Fifty docking solutions for each ligand in each protein model were generated and energetically scored. Thus, one thousand $(2 \times 10 \times 50)$ docking solutions for each protein molecule were analyzed. All the results were evaluated to explore binding modes and their energies for different sites. The binding energy maps were plotted with PyMOL (version 1.7.4, The PyMOL Molecular Graphics System; Schrödinger, LLC: New York, NY, USA).

\subsection{Statistical Analysis}

Data are reported as the mean \pm SD of at least three experiments. Statistical analysis was determined by one-way ANOVA followed by Tukey's HSD post-hoc test (GraphPad Prism 5 software package, version 5.02, GraphPad Software Inc., San Diego, CA, USA). Statistical significance was considered at $p<0.05$.

\section{Results}

The current research is part of our on-going study to search for biologically active compounds against $\mathrm{AD}$ using our library of plant-derived natural products and synthetic compounds. Prioritization was done on new entities with no reported biological activities. In the present study, diaportheone A1 and diaportheone A2 (Figure 1) are synthetic scaffolds with no reported molecular targets. We tested their potential as $\mathrm{A} \beta$ aggregation inhibitors and neuroprotective agents using in vitro and molecular docking.<smiles>COc1cccc2oc3c(c(=O)c12)[C@H](O)CC3</smiles>

(a)<smiles>COc1cccc2oc3c(c(=O)c12)[C@H](O)CC3</smiles>

(b)

Figure 1. Structure of (a) Diaportheone A1 and (b) Diaportheone A2.

\subsection{Effects of Diaportheone A1 and Diaportheone A2 on Thioflavin T (ThT) Assay}

The effects of the compounds (Figure 1 ) to inhibit the $A \beta$ aggregation was evaluated using the ThT fluorescence assay. The measured fluorescence in the assay was the result of the binding of the ThT to the $A \beta$ aggregates. $A \beta(10 \mu \mathrm{M})$ solutions were incubated with the compounds at 5 and $50 \mu \mathrm{M}$ concentrations for $24 \mathrm{~h}$. Diaportheone A1 (S-1-hydroxy-8methoxy-2,3-dihydrocyclopenta[ $b]$ chromen-9(1H)-one) exhibited $80.41 \% \pm 1.40$ inhibition at $50 \mu \mathrm{M}$, and $34.75 \% \pm 2.5$ inhibition at $5 \mu \mathrm{M}$ concentration. Diaportheone A2 (R-1hydroxy-8-methoxy-2,3-dihydrocyclopenta[b]chromen-9(1H)-one) showed 73.68\% \pm 1.70 (at $50 \mu \mathrm{M})$ and $35.21 \% \pm 2.80(5 \mu \mathrm{M})$ inhibitions. All percentage inhibitions (Table 1) exhibited significant difference $(p<0.05)$, with phenol red as the positive control $[28,29]$ $(65.78 \% \pm 2.97$ at $50 \mu \mathrm{M})$.

Table 1. Results of the Thioflavin-T (ThT) assay on Diaportheones A1 and A2.

\begin{tabular}{cc}
\hline & \% Inhibition of A $\boldsymbol{\beta}_{\mathbf{1 - 4 2}}$ Aggregation $^{\text {a }}$ \\
\hline Diaportheone A1 $(5 \mu \mathrm{M})$ & $34.75 \% \pm 2.5^{*}$ \\
Diaportheone A1 $(50 \mu \mathrm{M})$ & $80.41 \% \pm 1.40^{*}$ \\
Diaportheone A2 $(5 \mu \mathrm{M})$ & $35.21 \% \pm 2.80^{*}$ \\
Diapotheone A2 $(50 \mu \mathrm{M})$ & $73.68 \% \pm 1.70^{*}$ \\
Phenol Red $(50 \mu \mathrm{M})($ Positive control) & $65.78 \% \pm 2.97$ \\
\hline
\end{tabular}

a The values are expressed as the mean $\pm \mathrm{SD}(n=3) .{ }^{*}$ Significant difference $(p<0.05)$ with the positive control using one-way ANOVA. 


\subsection{Cytotoxicity of Diaportheone A1 and Diaportheone A2}

The cell viability of the compounds was evaluated at different concentrations $(1,10$, $50 \mu \mathrm{M}$ ) after $24 \mathrm{~h}$ of treatment (Figure 2) using the ATP luminescence assay. Both compounds did not show any significant cytotoxicity when compared to the control cells. Both the 1 and $10 \mu \mathrm{M}$ concentrations exhibited $>95 \%$ cell viability. At the highest concentration $(50 \mu \mathrm{M}), 83 \%$ cell viability for diaportheone A1 and 80\% cell viability for diaportheone A2 were observed, which exhibited statistically significant differences $(p<0.05)$ when compared to the control cells. Hence, to minimize the inhibition effect of the compounds against the neuroblastoma cells, the succeeding neuroprotective experiments used 1, 10 and $20 \mu \mathrm{M}$ concentrations.
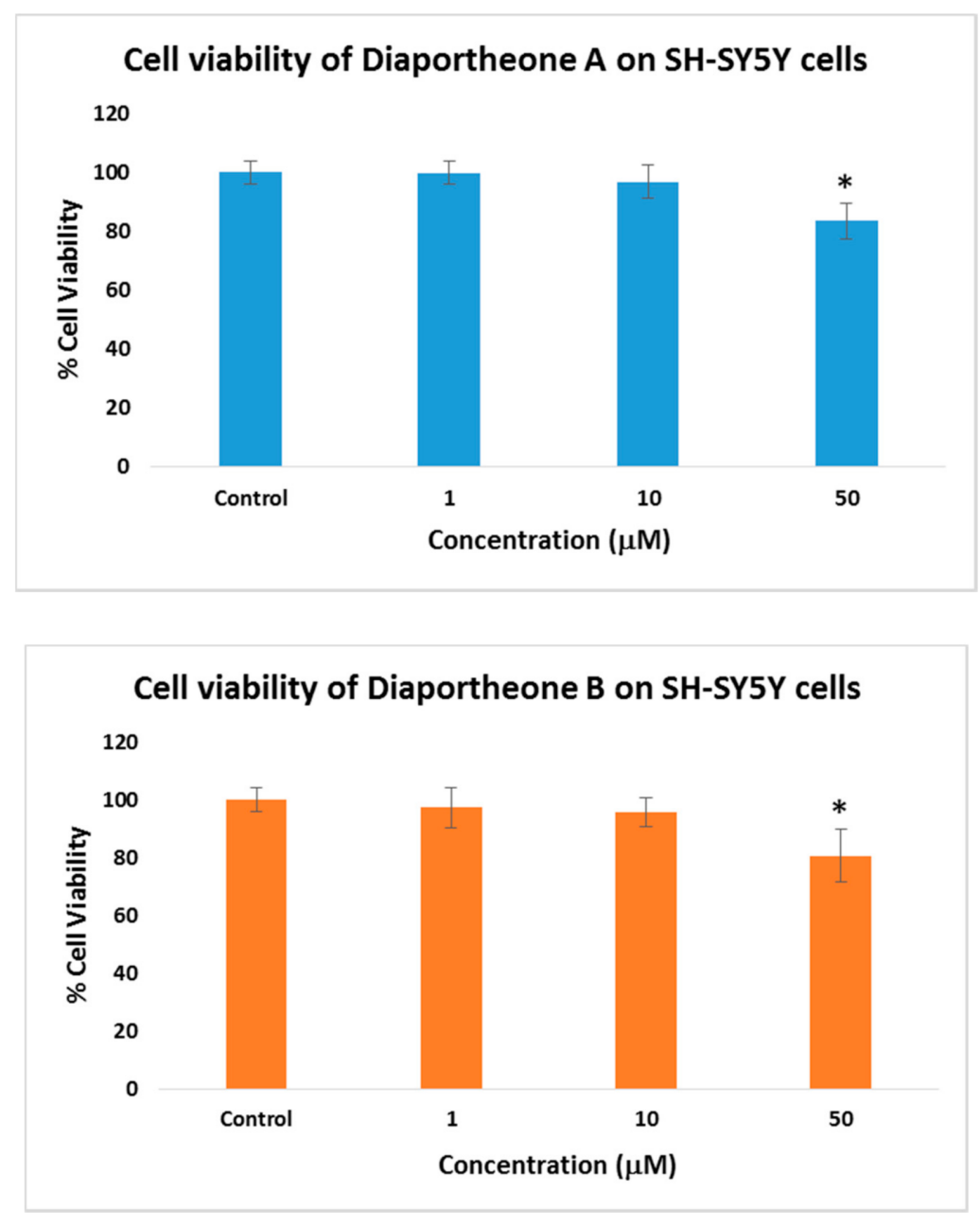

Figure 2. Cytotoxic effects of diaportheone A1 and diaportheone A2 on the neuroblastoma SHSY5Y cells measured using the ATP assay. The cells were treated for $24 \mathrm{~h}$ with varying compound concentrations. The cell viability is reported as percentage of the control group $(0 \mu \mathrm{M}$ set as $100 \%)$. All data are presented as mean $\pm \operatorname{SEM}(n=3)$. Significant difference $\left(^{*}\right)(p<0.05)$ using one-way ANOVA followed by Tukey's test was observed to the \% cell viability vs the control group.

\subsection{Neuroprotective Effects of Diaportheone A1 and Diaportheone A2}

The neuroprotective effects of the compounds were evaluated using $A \beta$-induced and $\mathrm{H}_{2} \mathrm{O}_{2}$-induced neuroblastoma SH-SY5Y cells. For the A $\beta$-induced treatment (Figure 3 ), the cells were pretreated with the compounds for $6 \mathrm{~h}$ followed by treatment with the $A \beta(5 \mu \mathrm{M})$ for $24 \mathrm{~h}$. Similarly, the cell viability was also compared to the cells treated only with the compounds for $24 \mathrm{~h}$. As presented in Figure 3, the cells treated only with the compounds at 20,10 and $1 \mu \mathrm{M}$ concentrations did not show cytotoxic effects (cell viability >95\%) 
when compared to the control cells. The cells treated with $\mathrm{A} \beta$ only $(5 \mu \mathrm{M})$ showed a $54.41 \%( \pm 5.1)$ cell viability. The SH-SY5Y cells pre-treated with the compounds for $6 \mathrm{~h}$, followed by treatment with $\mathrm{A} \beta(5 \mu \mathrm{M})$ for $24 \mathrm{~h}$, exhibited significant increases in the cell viability $(p<0.05)$ at $10 \mu \mathrm{M}(76.81 \% \pm 2.31)$ and $20 \mu \mathrm{M}(83.79 \% \pm 2.02)$ concentrations for diaportheone $\mathrm{A} 1$, and $20 \mu \mathrm{M}(81.05 \% \pm 2.41)$ concentration for diaportheone $\mathrm{A} 2$ in comparison to the $A \beta$-treated alone cells. None of the compounds showed neuroprotective effects $(p<0.05)$ using the $1 \mu \mathrm{M}$ concentration.
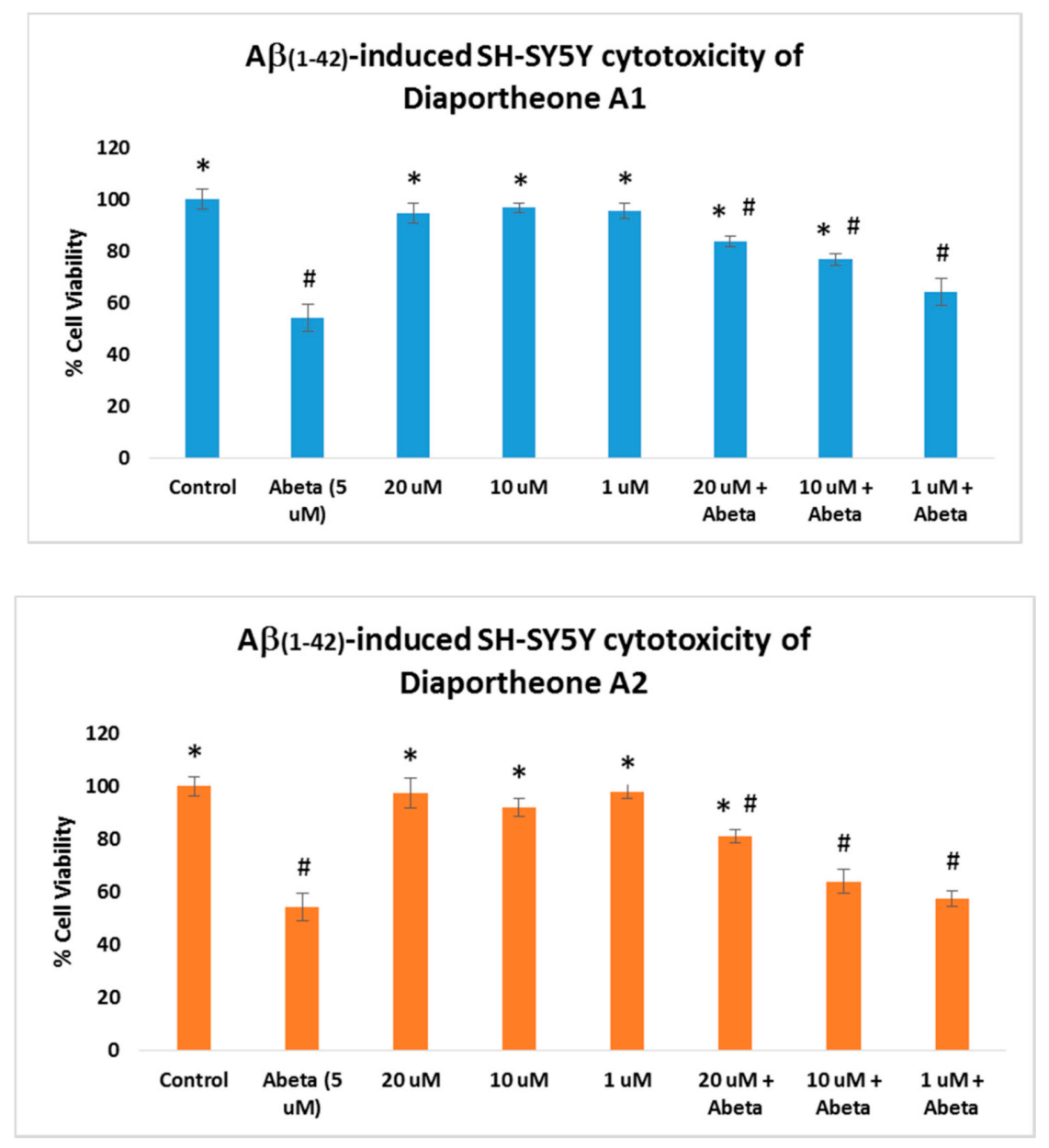

Figure 3. Neuroprotective effects of diaportheone A1 and diaportheone A2 on A $\beta$-induced neuroblastoma SH-SY5Y cells. The SH-SY5Y cells with the compounds only were incubated for 24 h. For the A $\beta$-treated cells, the SH-SY5Y cells were incubated with the compounds for $6 \mathrm{~h}$, followed by $\mathrm{A} \beta$-treatment $(5 \mu \mathrm{M})$ for $24 \mathrm{~h}$. Results indicate $\%$ cell viability vs. the control cells (mean \pm SEM of triplicate trials). Statistical difference $(p<0.05)$ using one-way ANOVA followed by Tukey's test of the $\%$ cell viability versus the $A \beta$ (Abeta at $5 \mu \mathrm{M}$ )-treated alone group $\left(^{*}\right.$ ) or the control group (\#).

The neuroprotective effects of the compounds on oxidative stress were also explored by treating the SH-SY5Y cells with $100 \mu \mathrm{M} \mathrm{H}_{2} \mathrm{O}_{2}$. As shown in Figure 4, SH-SY5Y cells treated only with the compounds at 1,10 , and $20 \mu \mathrm{M}$ concentrations for $24 \mathrm{~h}$ did not exhibit cytotoxicity (cell viability $>95 \%$ ). In a parallel experiment, SH-SY5Y cells were pretreated with the compounds for $6 \mathrm{~h}$, followed by $\mathrm{H}_{2} \mathrm{O}_{2}$ treatment for $24 \mathrm{~h}$. The $\mathrm{H}_{2} \mathrm{O}_{2}$ alone treated cells for $24 \mathrm{~h}$ showed $59.43 \%( \pm 2.01)$ cell viability. When compared to the SH-SY5Y cells treated both with the compounds and $\mathrm{H}_{2} \mathrm{O}_{2}$, the induced cytotoxicity generated by the $\mathrm{H}_{2} \mathrm{O}_{2}$ was attenuated by both compounds at $10 \mu \mathrm{M}$ and $20 \mu \mathrm{M}$ concentrations. Diaportheone A1 showed $68.73 \% \pm 3.21($ at $10 \mu \mathrm{M})$ and $74.62 \% \pm 3.42($ at $20 \mu \mathrm{M})$, while diaportheone A2 gave $69.75 \% \pm 4.51($ at $10 \mu \mathrm{M})$ and $68.73 \% \pm 5.33$ (at $20 \mu \mathrm{M})$. No neuro- 
protective effect was observed for both compounds at $1 \mu \mathrm{M}$. The underlying mechanism involved in the neuroprotective effects was investigated utilizing the measurement of the ROS and the mitochondrial membrane potential.
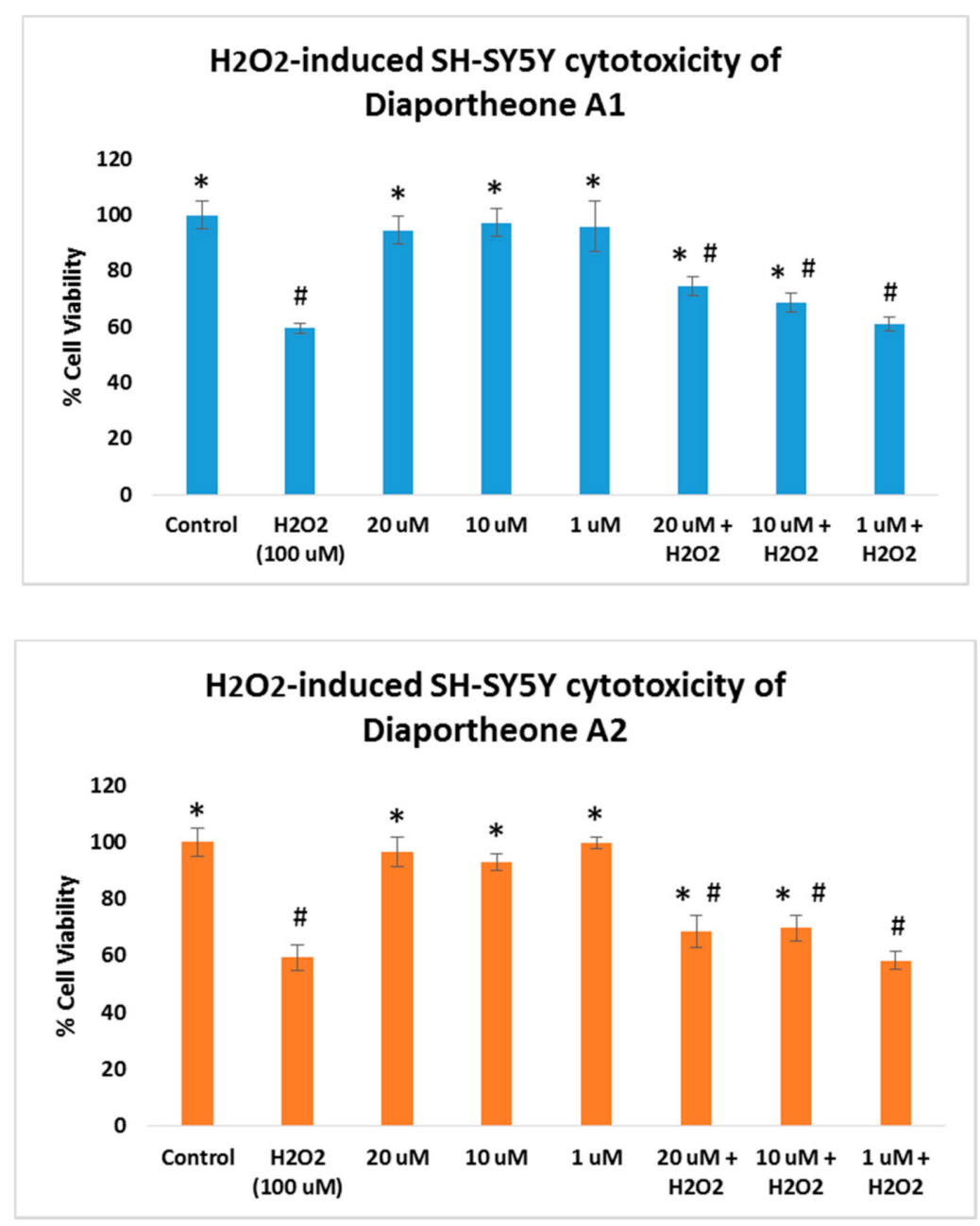

Figure 4. Neuroprotective effects of diaportheone A1 and diaportheone A2 on $\mathrm{H}_{2} \mathrm{O}_{2}$-induced neuroblastoma SH-SY5Y cells. The SH-SY5Y cells treated with the compounds only were incubated for $24 \mathrm{~h}$. For the $\mathrm{H}_{2} \mathrm{O}_{2}$-treated cells, the SH-SY5Y cells were incubated with the compounds for $6 \mathrm{~h}$, followed by $\mathrm{H}_{2} \mathrm{O}_{2}$-treatment $(100 \mu \mathrm{M})$ for $24 \mathrm{~h}$. Results indicate \% cell viability vs. the control cells (mean \pm SEM, $n=3$ ). Statistical difference $(p<0.05)$ using one-way ANOVA followed by Tukey's test of the \% cell viability versus the $\mathrm{H}_{2} \mathrm{O}_{2}$-treated $(100 \mu \mathrm{M})$ alone group (*) or the control group (\#).

\subsection{Effects on Intracellular Reactive Oxygen Species (ROS) Production}

The level of ROS generation in $\mathrm{A} \beta$ - or $\mathrm{H}_{2} \mathrm{O}_{2}$-induced SH-SY5Y cells was evaluated using $2^{\prime}, 7^{\prime}$-dichlorodihydrofluorescein diacetate $\left(\mathrm{H}_{2}\right.$ DCFDA) reagent. In Figure 5, $\mathrm{H}_{2} \mathrm{O}_{2}$ $(100 \mu \mathrm{M})$ was used in the generation of intracellular ROS in the SH-SY5Y cells. Initially, cells were pretreated with compounds for $2 \mathrm{~h}$ before incubating with the $\mathrm{H}_{2} \mathrm{O}_{2}$ for $4 \mathrm{~h}$. The reduction in the incubation time with $\mathrm{H}_{2} \mathrm{O}_{2}$ is a result of the observed \% cell viability (Figure 4), which also caused a decrease of fluorescence [21]. The SY-SY5Y cells treated with $\mathrm{H}_{2} \mathrm{O}_{2}$ only generated $255.78 \% \pm 4.52$ level of ROS. Treating the SH-SY5Y cells with $20 \mu \mathrm{M}$ of the compounds showed a significant reduction $(p<0.05)$ in the ROS level, with $199.67 \% \pm 3.58$ for diaportheone A1 (Figure 5A) and 205.53\% \pm 2.34 for diaportheone A2 (Figure $5 \mathrm{~B}$ ) when compared to the $\mathrm{H}_{2} \mathrm{O}_{2}$-alone cells. At $10 \mu \mathrm{M}$ and $1 \mu \mathrm{M}$ concentrations, the level of ROS is comparable $(p<0.05)$ to the $\mathrm{H}_{2} \mathrm{O}_{2}$-alone cells. The intracellular ROS without $\mathrm{H}_{2} \mathrm{O}_{2}$ treatment (no oxidative stress) was also evaluated by treating the SH-SY5Y 
cells with the compounds for $6 \mathrm{~h}$. Results indicated in the no oxidative stress group showed comparable effects to the control cells.

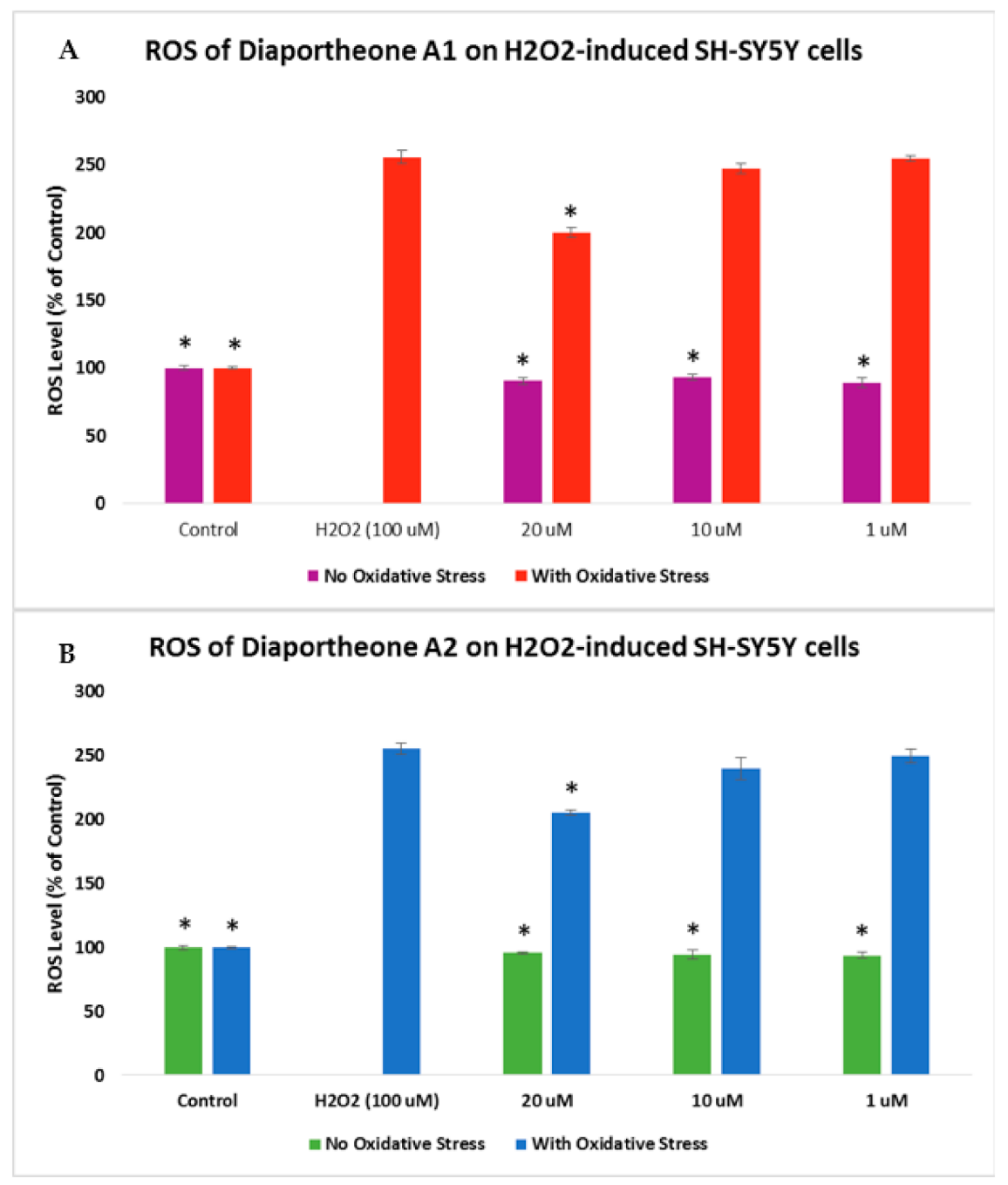

Figure 5. Effects of diaportheone A1 (A) and diaportheone A2 (B) on $\mathrm{H}_{2} \mathrm{O}_{2}$-induced intracellular ROS accumulation. The level of ROS in neuroblastoma SH-SY5Y cells was evaluated using $2^{\prime}, 7^{\prime}$. dichlorodihydrofluorescein diacetate $\left(\mathrm{H}_{2}\right.$ DCFDA) reagent. SH-SY5Y cells were pretreated with the compounds for $2 \mathrm{~h}$, followed by treatment with $100 \mu \mathrm{M} \mathrm{H}_{2} \mathrm{O}_{2}$ for $4 \mathrm{~h}$. No Oxidative Stress indicates treatment of the SH-SY5Y cells only with the compounds. The intracellular ROS level (\% of the control cells) was expressed as the mean $\pm \operatorname{SEM}(n=3)$. The $\left(^{*}\right)$ represents statistical difference $(p<0.05)$ of the \% ROS versus the $\mathrm{H}_{2} \mathrm{O}_{2}$-treated alone group using one-way ANOVA followed by Tukey's test.

The effect of the compounds on the ROS generation in A $\beta$-induced SH-SY5Y cells was also evaluated. The cells were pretreated with the compounds for $2 \mathrm{~h}$ before incubating with $5 \mu \mathrm{M} A \beta$ for $24 \mathrm{~h}$ [30]. As shown in Figure 6, a 150.79\% $\pm 3.44 \mathrm{ROS}$ level was generated when the cells were treated only with A $\beta$ for $24 \mathrm{~h}$. When the SH-SY5Y cells were pretreated for $2 \mathrm{~h}$ with the compounds before $A \beta$ exposure for $24 \mathrm{~h}$, a significant decrease $(p<0.05)$ in the ROS level was observed at $10 \mu \mathrm{M}(136.94 \% \pm 3.41)$ and $20 \mu \mathrm{M}(133.04 \% \pm 2.65)$ for diaportheone A1 (Figure 6A), and at $10 \mu \mathrm{M}(132.74 \% \pm 3.59)$ and $20 \mu \mathrm{M}(129.67 \% \pm 4.52)$ for diaportheone A2 (Figure 6B). 


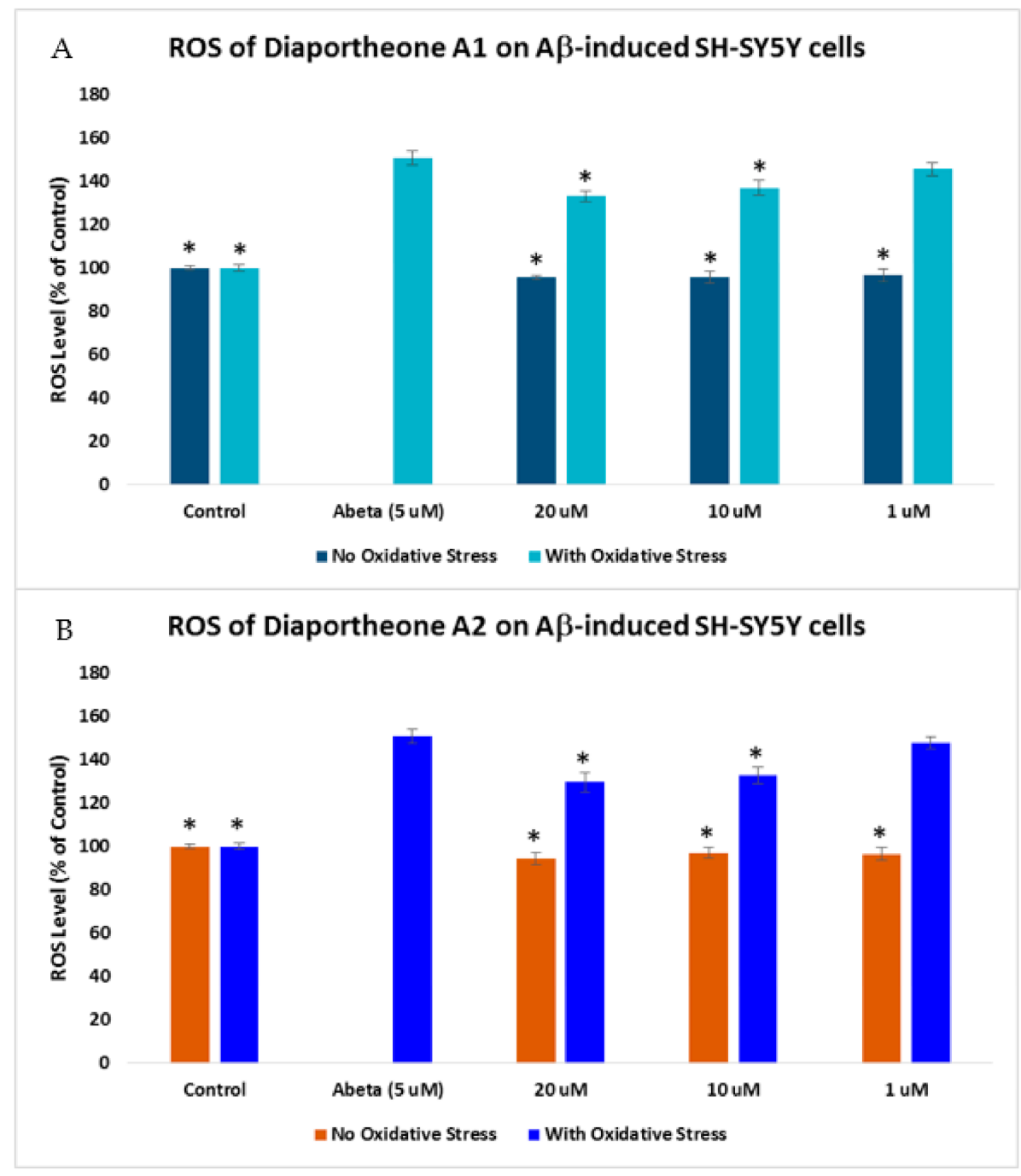

Figure 6. Effects of diaportheone A1 (A) and diaportheone A2 (B) on A $\beta$-induced intracellular ROS accumulation. The level of ROS in neuroblastoma SH-SY5Y cells was evaluated using $2^{\prime}, 7^{\prime}$ dichlorodihydrofluorescein diacetate $\left(\mathrm{H}_{2} \mathrm{DCFDA}\right)$ reagent. SH-SY5Y cells were pretreated with the compounds for $2 \mathrm{~h}$, followed by treatment with $5 \mu \mathrm{M} \mathrm{A} \beta$ (Abeta) for $24 \mathrm{~h}$. No Oxidative Stress indicates treatment of the SH-SY5Y cells only with the compounds. The intracellular ROS level (\% of the control cells) was expressed as the mean $\pm \operatorname{SEM}(n=3)$. The $\left(^{*}\right)$ represents statistical difference $(p<0.05)$ of the \% ROS versus the Abeta-treated alone group using one-way ANOVA followed by Tukey's test.

\subsection{Effects on Mitochondrial Membrane Potential}

As the increase of ROS accumulation is the result of mitochondrial dysfunction, the effects of the compounds on mitochondrial membrane potential $(\triangle \Psi \mathrm{m})$ were evaluated using the TMRE staining assay. The $\triangle \Psi \mathrm{m}$ was conducted in A $\beta$-induced SH-SY5Y cells as both compounds showed ROS protection at $10 \mu \mathrm{M}$ and $20 \mu \mathrm{M}$ concentrations. The SH-SY5Y cells were pretreated with the compounds for $2 \mathrm{~h}$, followed by A $\beta(5 \mu \mathrm{M})$ for $24 \mathrm{~h}$. As presented in Figure 7, a significant increase $(p<0.05)$ when compared to the A $\beta$ treated only $(64.79 \% \pm 2.56)$ cells was observed at $20 \mu \mathrm{M}$ concentration for diaportheone A1 $(79.02 \% \pm 3.85)$ and diaportheone A2 $(78.95 \% \pm 3.01)$. None of the compounds showed a significant effect at $10 \mu \mathrm{M}$ on this parameter. SH-SY5Y cells treated only with the compounds gave a similar $\Delta \Psi \mathrm{m}$ level with the control cells. 


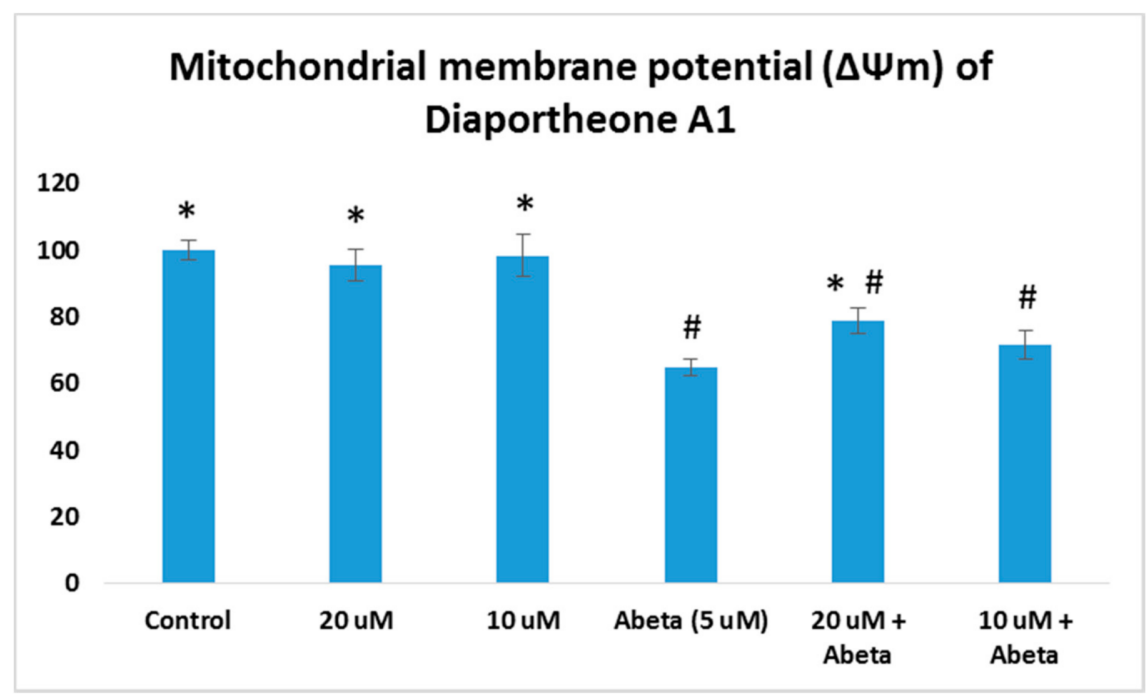

\section{Mitochondrial membrane potential $(\Delta \Psi \mathrm{m})$ of Diaportheone A2}

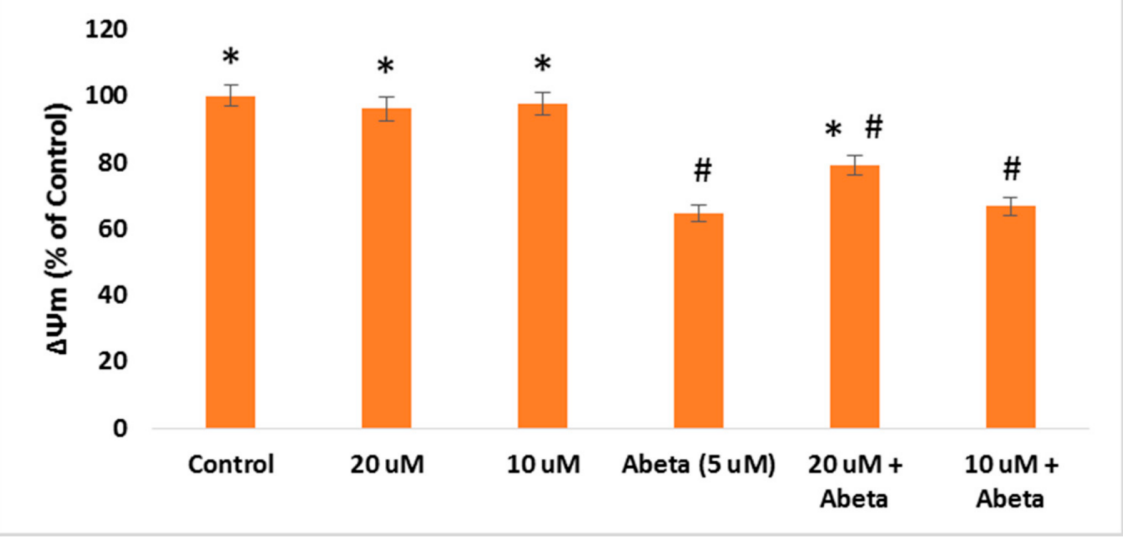

Figure 7. Effects on the mitochondrial membrane potential $(\triangle \Psi \mathrm{m})$ of diaportheone $\mathrm{A} 1$ and diaportheone A2. $\Delta \Psi \mathrm{m}$ were evaluated in A $\beta$-treated (5 $\mu \mathrm{M})$ SH-SY5Y cells using the tetramethylrhodamine, methyl ester (TMRE) assay. Cells were pretreated with the compounds for $2 \mathrm{~h}$, followed by $\mathrm{A} \beta$ treatment for $24 \mathrm{~h}$. The $\Delta \Psi \mathrm{m}$ ( $\%$ of the control cells) was expressed as the mean $\pm \operatorname{SEM}(n=3)$. Statistical difference $(p<0.05)$ of the $\Delta \Psi$ m versus the Abeta-treated alone group $\left({ }^{*}\right)$ or the control group (\#) using one-way ANOVA followed by Tukey's test.

\subsection{Molecular Docking}

In order to explore the structural basis of $A \beta$ aggregation inhibition by diaportheone $\mathrm{A} 1$ and diaportheone $\mathrm{A} 2$, molecular docking was performed. Two protein NMR structures of $\mathrm{A} \beta_{1-42}, 2 \mathrm{BEG}$ (pentamer) and $2 \mathrm{MXU}$ (dodecamer) were used for molecular docking, as they have different oligomeric composition [26,27]. Ten available conformational NMR models for both 2BEG and 2MXU were examined for $\mathrm{A} \beta_{1-42}$-ligand interactions. Having the reference data from other work [31], three main sites were found, the 2BEG conformer (Figure 8a-c). 


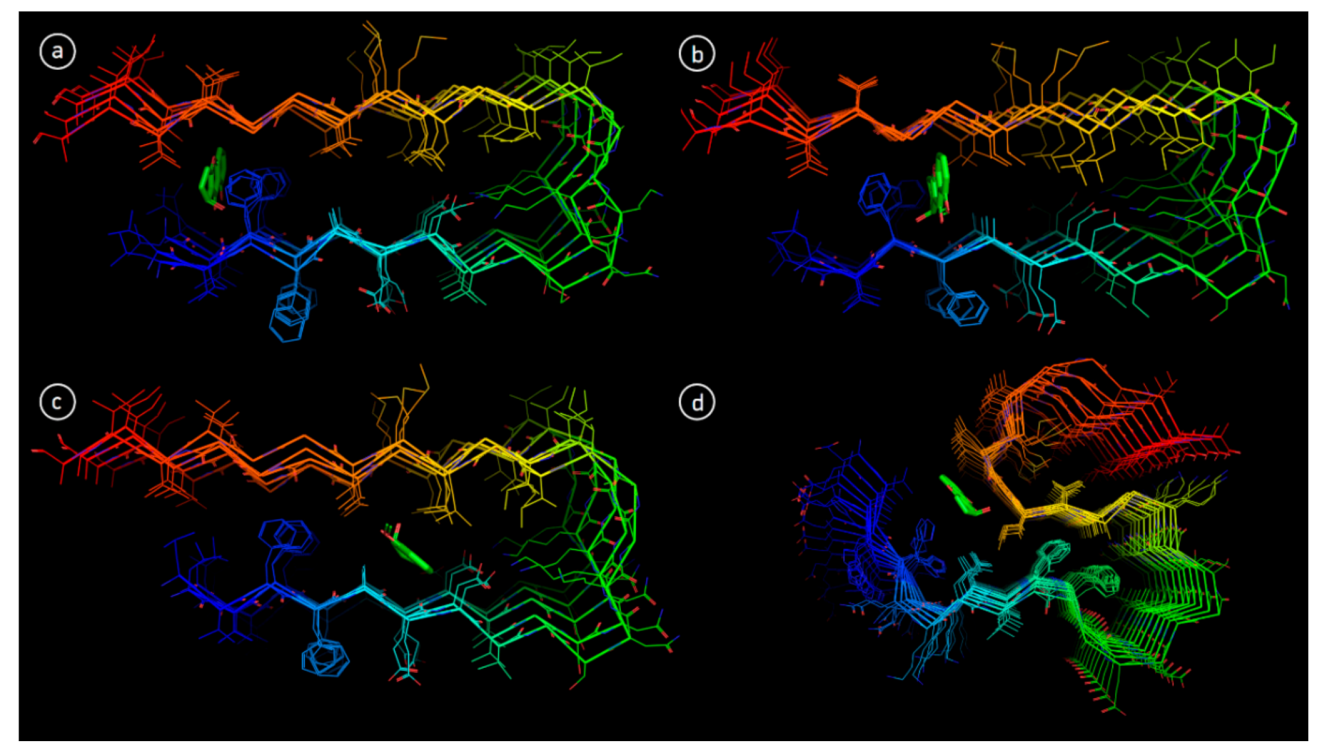

Figure 8. Binding modes of diaportheone A1 in A $\beta$ fibril revealed by molecular docking; (a) 2BEG, site 1, model 1; (b) 2BEG, site 2, model 5; (c) 2BEG, site 3, model 8; (d) 2MXU, model 1.

Site 1 is formed by residues Leu17, Val18, Phe19, Gly38, Val39 and presented in 6 out of 10 NMR models (Models 1, 2, 3, 6, 8, 10 in Table 2). Site 2 is composed of the residues Phe19, Phe20 and Gly37 and relevant only for models 7, 8 and 9. Site 3 is shaped by residues Ala21, Glu22 and Asp23 (applicable for models 4, 5 and 7). By comparison of the binding affinities of diaportheone A1 and diaportheone A2, the docking results of each model showed moderate differences (Table 2). In the position of site 1, diaportheone A1 is more favorable for most of the models except for models 1 and 3. At Site 2, diaportheone A1 and diaportheone A2 have comparable binding affinities. At Site 3, models 4 and 7 showed the privilege of diaportheone A1 ( -6.8 and $-8.1 \mathrm{kcal} / \mathrm{mol}$ compared to -6.6 and $-7.4 \mathrm{kcal} / \mathrm{mol}$ for diaportheone A2). Model 5 showed a slight gain of diaportheone A2 $(-8.8 \mathrm{kcal} / \mathrm{mol}$ and for diaportheone $\mathrm{A} 1-8.7 \mathrm{kcal} / \mathrm{mol})$.

Table 2. Docking-Predicted Binding Affinities $(\mathrm{kcal} / \mathrm{mol})$ for the A $\beta$ templates 2BEG and 2MXU. For the 2BEG template: black—site 1, red-site 2, green-site 3.

\begin{tabular}{ccccc}
\hline \multirow{2}{*}{ Model } & \multicolumn{3}{c}{ 2MXU } & \multicolumn{2}{c}{ 2BEG } \\
\cline { 2 - 5 } & Diaportheone A1 & Diaportheone A2 & Diaportheone A1 & Diaportheone A2 \\
\hline 1 & -8.0 & -7.9 & -10.3 & -11.0 \\
2 & -5.8 & - & -8.7 & -8.6 \\
3 & -6.8 & -6.6 & -9.7 & -10.1 \\
4 & -8.3 & -8.5 & -6.8 & -6.6 \\
5 & -6.6 & -6.2 & -8.8 & -8.9 \\
6 & -7.3 & -6.9 & -10.4 & -9.7 \\
7 & - & - & -8.3 & -8.4 \\
& & & -8.1 & -7.4 \\
8 & -7.1 & -7.1 & -7.8 & -7.6 \\
9 & -7.5 & -7.2 & -10.7 & -10.8 \\
10 & -7.4 & -7.4 & -9.1 & -8.8 \\
\hline
\end{tabular}

Similarly, the docking performed for 2MXU with 10 different NMR models revealed few binding sites. In this case, only one and the most common site was extracted and have already been previously reported [32]. This site is delimited by residues Ile32, Gly33, Leu34 and Gln15 (Figure 8d). Docking results for 2MXU demonstrated more consistent trend, with only model 7 not showing any binding at chosen site. As exhibited in Table 2, for all 
the models except 4, diaportheone A1 showed better binding affinity when compared to diaportheone $\mathrm{A} 2$.

\section{Discussion}

Chromones are oxygen-bearing heterocyclic compounds containing the benzoannelated $\gamma$-pyrone moiety. They comprised a group of chemically varied structures that are isolated in nature. Pharmacological activities identified with the chromones included anti-inflammatory, antimicrobial, antitumor, anti-diabetic, diuretics, hypoglycemic, hypolipidemic, antioxidant, and neurodegenerative enzyme inhibitors [33]. The chromone structure is an excellent target in medicinal chemistry due to their structural diversity and synthetic accessibility [29]. The synthetic and natural chromone compounds with reported anti-neurodegenerative effects were limited to acetylcholinesterase (AChE), $\beta$-secretase- 1 (BACE-1), and monoamine oxidase B (MAO-B) inhibitors and serotonin receptors [33,34].

The present study of synthetic chromones diaportheone A1 and diaportheone A2 presented information on their inhibitory activity against $A \beta$ aggregation and neuroprotective effects against the oxidative stressors $\mathrm{A} \beta$ - or $\mathrm{H}_{2} \mathrm{O}_{2}$-induced human neuroblastoma SH-SY5Y cells. Both chromones were synthetic intermediates as racemic mixture in the total synthesis of diaportheone A [35]. They were resolved by chiral supercritical fluid chromatography in $>99 \%$ enantiometic excess and their absolute configuration was unambiguously determined by $\mathrm{X}$-ray crystallography [35]. Structurally, the methoxy group $\left(-\mathrm{OCH}_{3}\right)$ in diaportheones $\mathrm{A} 1$ and $\mathrm{A} 2$ is replaced by a hydroxyl group in diaportheone A. To the best of our knowledge, this is the first report on the biological activities of these chromones.

The development of an effective drug for the treatment of AD was challenging, even after many investigations with diverse isolated natural products and synthetic compounds [36]. Many complex biochemical and metabolic pathways were intertwined in AD progressions and pathogenicity. Being a multifaceted illness, a drug for targeting multiple pathological hallmarks of $\mathrm{AD}$ should be envisioned as a possible avenue for the treatment of the disease, instead of concentrating on only one pathological target [24].

In this study, both compounds were able to inhibit the aggregation of $A \beta$ as evaluated in the ThT assay. To further explore their potential, the neuroprotective effects in damaged neuroblastoma SH-SY5Y cells were investigated. In the A $\beta$-induced SH-SY5Y cells or $\mathrm{H}_{2} \mathrm{O}_{2}$ treated SY-SY5Y cells, an increase in the cell viability was observed, thereby avoiding the cytotoxic effects in the SH-SY5Y cells of either $\mathrm{A} \beta$ or $\mathrm{H}_{2} \mathrm{O}_{2}$. A possible mechanism involves the reduction of the oxidative stress. Oxidative stress is a known characteristic of chronic and acute illnesses, including neurodegenerative diseases. The presence of oxidative stress would also lead to mitochondrial dysfunctions as a result of an increased ROS. As a consequence, the buildup of oxidative damages leads to neuronal death causing age-related illnesses including AD. The reductions of ROS generation in the SH-SY5Y cells after $\mathrm{H}_{2} \mathrm{O}_{2}$ or $\mathrm{A} \beta$ treatments were successfully manifested by diaportheone $\mathrm{A} 1$ and diaportheone $\mathrm{A} 2$. Results also indicated that both compounds decreased the mitochondrial dysfunctions by elevating the mitochondrial membrane potential in A $\beta$-induced SH-SY5Y cells.

Molecular docking studies of $\mathrm{A} \beta$ with diaportheone $\mathrm{A} 1$ and diaportheone $\mathrm{A} 2$ suggested that these scaffolds can interact with $\mathrm{A} \beta$ oligomers, thus, presumably, blocking aggregation. The protein model $2 \mathrm{MXU}$ demonstrated increased affinity to diaportheone A1 compared to diaportheone A2, which is in good agreement with experimental data.

Taken together, the chromones diaportheone A1 and diaportheone A2 could be promising compounds for $\mathrm{AD}$ treatment. The manifested neuroprotective effects on damaged neuroblastoma SH-SY5Y cells of the two compounds may be due to their inhibitory activity on $A \beta$ aggregation and protection against oxidative stress by decreasing the ROS and increasing the mitochondrial membrane potential. Our further perspectives also deal with the structure-activity relationship studies of racemic mixtures and the design of other chromone analogues. In addition, non-mitochondrial cytoprotective mechanisms, use 
of other microglial cells [37], and an in vivo assessment are significant considerations to evaluate their potential as therapeutic agents against AD.

\section{Conclusions}

Chromones are heterocyclic and pharmacologically active molecules existing as natural products or synthetic compounds. The current study reports the first biological activity of the synthetic chromones diaportheone A1 and diaportheone A2. Their neuroprotective potentials were systematically evaluated in vitro using a single viability assay and their capacity to inhibit the $\mathrm{A} \beta$ aggregation was determined by ThT assay and molecular docking. Hence, this study provided promising scaffolds for anti-AD drug development research.

Author Contributions: Conceptualization, M.A.T. and S.S.A.A.; methodology, M.A.T.; formal analysis, M.A.T.; writing—original draft preparation, M.A.T.; writing—review and editing, M.A.T., S.S.A.A. and E.Z.; project administration, M.A.T. and S.S.A.A.; molecular docking, E.Z.; funding acquisition, S.S.A.A. All authors have read and agreed to the published version of the manuscript.

Funding: This research was funded by the National Research Foundation of Korea (NRF) Grants, awarded by the Korean government (NRF 2020R1A2B5B01002463).

Institutional Review Board Statement: Not applicable.

Informed Consent Statement: Not applicable.

Data Availability Statement: The data presented in this study are available on request from the corresponding author. The data are not publicly available due to privacy restrictions.

Acknowledgments: The synthesis of the compounds was done by M.A.T. through a Next Generation Scientist (NGS) fellowship grant given by Novartis Pharma, Basel, Switzerland. The authors also acknowledge Vladimir M. Gorbachev for the technical assistance on the molecular docking experiments.

Conflicts of Interest: The authors declare no conflict of interest.

\section{References}

1. Bagyinszky, E.; Giau, V.V.; Shim, K.; Suk, K.; An, S.S.A.; Kim, S. Role of inflammatory molecules in the Alzheimer's disease progression and diagnosis. J. Neurol. Sci. 2017, 376, 242-254. [CrossRef] [PubMed]

2. Xia, C.-L.; Tang, G.-H.; Guo, Y.-Q.; Xu, Y.-K.; Huang, Z.-S.; Yin, S. Mulberry Diels-Alder-type adducts from Morus alba as multi-targeted agents for Alzheimer's disease. Phytochem 2019, 157, 82-91. [CrossRef] [PubMed]

3. Lin, Y.; Huang, K.; Xu, H.; Qiao, Z.; Cai, S.; Wang, Y.; Huang, L. Predicting the progression of mild cognitive impairment to Alzheimer's disease by longitudinal magnetic resonance imaging-based dictionary learning. Clin. Neurophysiol. 2020, 131, 2429-2439. [CrossRef]

4. Poloni, K.M.; Duarte de Oliveira, I.A.; Tam, R.; Ferrari, R.J. Brain MR image classification for Alzheimer's disease diagnosis using structural hippocampal asymmetrical attributes from directional 3-D log-Gabor filter responses. Neurocomputing 2021, 419, 126-135. [CrossRef]

5. $\quad$ Reus, L.M.; Stringer, S.; Posthuma, D.; Teunissen, C.E.; Scheltens, P.; Pijenburg, Y.; Visser, P.J.; Tijms, B.M. Degree of genetic liability for Alzheimer's disease associated with specific proteomic profiles in cerebrospinal fluid. Neurobiol. Aging 2020, 93, e1-e15. [CrossRef]

6. Emmerzaal, T.L.; Kiliaan, A.J.; Gustafson, D.R. 2003-2013: A decade of body mass index, Alzheimer's disease, and dementia. J. Alzheimers Dis. 2015, 43, 739-755. [CrossRef] [PubMed]

7. Alghazwi, M.; Smid, S.; Musgrave, I.; Zhang, W. In vitro studies of the neuroprotective activities of astaxanthin and fucoxanthin against amyloid beta $\left(\mathrm{A} \beta_{1-42}\right)$ toxicity and aggregation. Neurochem. Int. 2019, 124, 215-224. [CrossRef] [PubMed]

8. Plotkin, S.; Cashman, N.R. Passive immunotherapies targeting A $\beta$ and tau in Alzheimer's disease. Neurobiol. Dis. 2020, 144, 105010. [CrossRef]

9. Tang, K.S. The potential role of nanoyttria in alleviating oxidative stress biomarkers: Implications for Alzheimer's disease therapy. Life Sci. 2020, 259, 118287. [CrossRef]

10. Sieteiglesias, V.; Gonzalez-Burgos, E.; Bermejo-Bescos, P.; Divakar, P.K.; Gomez-Serranillos, M.P. Lichens of parmelioid clade as promising multitarget neuroprotective agents. Chem. Res. Toxicol. 2019, 32, 1165-1177. [CrossRef] [PubMed]

11. Nunomura, A.; Perry, G.; Aliev, G.; Hirai, K.; Takeda, A.; Balraj, E.K.; Jones, P.K.; Ghanbari, H.; Wataya, T.; Shimohama, S.; et al. Oxidative damage is the earliest event in Alzheimer disease. J. Neuropathol. Exp. Neurol. 2001, 60, 759-767. [CrossRef]

12. Montine, T.J.; Montine, K.S.; McMahan, W.; Markesbery, W.R.; Quinn, J.F.; Morrow, J.D. F2-isoprostanes in Alzheimer and other neurodegenerative diseases. Antioxid. Redox Signal 2005, 7, 269-275. [CrossRef] 
13. Reddy, P.H. Amyloid precursor protein-mediated free radicals and oxidative damage: Implications for the development and progression of Alzheimer disease. J. Neurochem. 2006, 96, 1-13. [CrossRef] [PubMed]

14. Mecocci, P.; Boccardi, V.; Cecchetti, R.; Bastiani, P.; Scamosci, M.; Ruggiero, C.; Baroni, M. A Long journey into aging, brain aging, and Alzheimer's disease following the oxidative stress tracks. J. Alzheimers Dis. 2018, 62, 1335-1399. [CrossRef]

15. Dey, A.; Bhattacharya, R.; Mukherjee, A.; Pandey, D.K. Natural products against Alzheimer's disease: Pharmaco-therapeutics and biotechnological interventions. Biotechnol. Adv. 2017, 35, 178-216. [CrossRef] [PubMed]

16. Zeng, K.; Ko, H.; Yang, H.; Wang, X. Icariin attenuates $\beta$-amyloid-induced neurotoxicity by inhibition of tau protein hyperphosphorylation in PC12 cells. Neuropharmacology 2010, 59, 542-550. [CrossRef] [PubMed]

17. Doig, A.J.; Derreumaux, P. Inhibition of protein aggregation and amyloid formation by small molecules. Curr. Opin. Struct. Biol. 2015, 30, 50-56. [CrossRef]

18. Hyman, L.M.; Franz, K.J. Probing oxidative stress: Small molecule fluorescent sensors of metal ions, reactive oxygen species, and thiols. Coord. Chem. Rev. 2012, 256, 2333-2356. [CrossRef] [PubMed]

19. Tan, M.A.; Lagamayo, M.W.D.; Alejandro, G.J.D.; An, S.S.A. Anti-amyloidogenic and cyclooxygenase inhibitory activity of Guettarda speciosa. Molecules 2019, 24, 4112. [CrossRef]

20. Tan, M.A.; Gonzalez, S.J.B.; Alejandro, G.J.D.; An, S.S.A. Neuroprotective effects of vomifoliol, isolated from Tarenna obtusifolia Merr. (Rubiaceae), against amyloid-beta $(1-42)$-treated neuroblastoma SH-SY5Y cells. 3 Biotech 2020, 10, 424. [CrossRef]

21. Gonzalez-Sarrias, A.; Nunez-Sanchez, M.A.; Tomas-Barberan, F.A.; Espin, J.C. Neuroprotective effects of bioavailable polyphenolderived metabolited against oxidative stress-induced cytotoxicity in human neuroblastoma SH-SY5Y cells. J. Agric. Food Chem. 2017, 65, 752-758. [CrossRef] [PubMed]

22. Yu, H.-Y.; Chen, Z.-Y.; Sun, B.; Liu, J.; Meng, F.-Y.; Liu, Y.; Tian, T.; Jin, A.; Ruan, H.-L. Lignans from the fruit of Schisandra glaucescens with antioxidant and neuroprotective properties. J. Nat. Prod. 2014, 77, 1311-1320. [CrossRef] [PubMed]

23. Peñalver, P.; Zodio, S.; Lucas, R.; de-Paz, M.V.; Morales, J.C. Neuroprotective and anti-inflammatory effects of pterostilbene metabolites in human neuroblastoma SH-SY5Y and RAW 264.7 macrophage cells. J. Agric. Food Chem. 2020, 68, 1609-1620. [CrossRef]

24. Alvariño, R.; Alonso, E.; Lacret, R.; Oves-Costales, D.; Genilloud, O.; Reyes, F.; Alfonso, A.; Botana, L.M.; Caniferolide, A. A macrolide from Streptomyces caniferus, attenuates neuroinflammation, oxidative stress, amyloid-beta, and tau pathology in vitro. Mol. Pharm. 2019, 16, 1456-1466. [CrossRef]

25. Morris, G.M.; Huey, R.; Lindstrom, W.; Sanner, M.F.; Belew, R.K.; Goodsell, D.S.; Olson, A.J. Autodock4 and AutoDockTools4: Automated docking with selective receptor flexiblity. J. Comp. Chem. 2009, 16, 2785-2791. [CrossRef]

26. Lührs, T.; Ritter, C.; Adrian, M.; Riek-Loher, D.; Bohrmann, B.; Döbeli, H.; Schubert, D.; Riek, R. 3D structure of Alzheimer's amyloid-beta(1-42) fibrils. Proc. Natl. Acad. Sci. USA 2005, 102, 17342-17347. [CrossRef]

27. Xiao, Y.; Ma, B.; McElheny, D.; Parthasarathy, S.; Long, F.; Hoshi, M.; Nussinov, R.; Ishii, Y. A $\beta(1-42)$ fibril structure illuminates self-recognition and replication of amyloid in Alzheimer's disease. Nat. Struct. Mol. Biol. 2015, 22, 499-505. [CrossRef] [PubMed]

28. Necula, M.; Kayed, R.; Milton, S.; Glabe, C.G. Small molecule inhibitors of aggregation indicate that amyloid $\beta$ oligomerization and fibrillization pathways are independent and distinct. J. Biol. Chem. 2007, 282, 10311-10324. [CrossRef]

29. Wu, C.; Lei, H.; Wang, Z.; Zhang, W.; Duan, Y. Phenol red interacts with the protofibril-like oligomers of an amyloidogenic hexapeptide NFGAIL through both hydrophobic and aromatic contacts. Biophys. J. 2006, 91, 3664-3672. [CrossRef] [PubMed]

30. Sereia, A.L.; de Oliveira, M.T.; Baranoski, A.; Marques, L.L.; Ribeiro, F.; Isolani, R.; de Medeiros, D.; Chierrito, D.; Bidoia, D.; Zielinski, A.; et al. In vitro evaluation of the protective effects of plant extracts against amyloid-beta peptide induced toxicity in human neuroblastoma SH-SY5Y cells. PLoS ONE 2019, 14, e0212089. [CrossRef]

31. Kuang, G.; Murugan, N.A.; Tu, Y.; Nordberg, A.; Agren, H. Investigation of the binding profiles of AZD2184 and Thioflavin T with amyloid- $\beta(1-42)$ fibril by molecular docking and molecular dynamics methods. J. Phys. Chem. B 2015, 119, 11560-11567. [CrossRef]

32. Espargaró, A.; Ginex, T.; Vadell, M.D.; Busquets, M.A.; Estelrich, J.; Muñoz-Torrero, D.; Luque, F.J.; Sabate, R. Combined in vitro cell-based/in silico screening of naturally occurring flavonoids and phenolic compounds as potential anti-Alzheimer drugs. J. Nat. Prod. 2017, 80, 278-289. [CrossRef] [PubMed]

33. Reis, J.; Gaspar, A.; Milhazes, N.; Borges, F. Chromone as a privileged scaffold in drug discovery: Recent advances. J. Med. Chem. 2017, 60, 7941-7957. [CrossRef] [PubMed]

34. Gaspar, A.; Matos, M.J.; Garrido, J.; Uriarte, E.; Borges, F. Chromone: A valid scaffold in medicinal chemistry. Chem. Rev. 2014, 114, 4960-4992. [CrossRef]

35. Tan, M.A.; Zueger, P.P.; Roggo, S. Total synthesis of diaportheone A. Tet. Lett. 2019, 60, 52-54. [CrossRef]

36. Brown, D.G.; Wobst, H.K. Opportunities and challenges in phenotypic screening for neurodegenerative disease research. J. Med. Chem. 2020, 63, 1823-1840. [CrossRef] [PubMed]

37. Cai, Z.; Hu, X.; Tan, R.; Feng, Y.; Sun, M.; Ma, N.; Li, X.; Huang, L.; An, J.; Ge, Q.; et al. Neuroprotective effect of green tea extractives against oxidative stress by enhancing the survival and proliferation of PC12 cells. Mol. Cell. Toxicol. 2019, 15, 391-397. [CrossRef] 